\title{
Characterization of Spherical NiO-YSZ Anode Composites for Solid Oxide Fuel Cells Synthesized by Ultrasonic Spray Pyrolysis
}

\author{
Chae-Hyun Lim* and Ki-Tae Lee****,; \\ *Division of Advanced Materials Engineering, Chonbuk National University, Jeonbuk 560-756, Korea \\ **Hydrogen and Fuel Cell Research Center, Chonbuk National University, Jeonbuk 561-756, Korea
}

(Received May 22, 2014; Revised June 18, June 27, 2014; Accepted June 30, 2014)

\begin{abstract}
Spherical NiO-YSZ particles were synthesized by ultrasonic spray pyrolysis (USP). The morphology of the synthesized particles can be modified by controlling parameters such as precursor $\mathrm{pH}$, carrier-gas flow-rate, and temperature of the heating zone. The synthesized spherical NiO-YSZ particles have rough surface morphology at high carrier-gas flow-rates due to rapid gas exhaustion and insufficient particle ordering. The Ni-YSZ cermet anode synthesized by ultrasonic spray pyrolysis at a flow rate of $1 \mathrm{~L} / \mathrm{min}$, with precursor solution at $\mathrm{pH}$, showed a higher maximum power density of $256 \mathrm{~mW} / \mathrm{cm}^{2}$ compared to a conventionally mixed Ni-YSZ anode $\left(185 \mathrm{~mW} / \mathrm{cm}^{2}\right)$ at $800^{\circ} \mathrm{C}$. While the area-specific resistance of conventionally mixed Ni-YSZ anodes increases gradually with operation time (indicating performance degradation), the Ni-YSZ anode synthesized by USP does not exhibit any performance degradation, even after $500 \mathrm{~h}$.
\end{abstract}

Key words : Solid oxide fuel cell, Anode material, Ultrasonic spray pyrolysis, Electrochemical performance, Long-term stability

\section{Introduction}

S olid-oxide fuel cells (SOFCs) are known as promising energy conversion systems due to their high efficiency. In addition, due to the high operating temperature of the fuel cells, hydrocarbon fuels can be used without external reforming. The primary reaction at the SOFC anode is the oxidation of a fuel. Nickel provides high catalytic activity for the oxidation of hydrogen gases to hydrogen ions. Usually, nickel is used with electrolyte materials such as yttria-stabilized zirconia (YSZ). The common term for this composite material is 'ceramic metal composite' (cermet). YSZ used in a Ni-YSZ cermet anode not only reduces the thermal expansion mismatch with the electrolyte but also provides ionic conductivity.

The oxidation reaction of the fuel at the anode occurs at the triple phase boundary (TPB - the three phase interface of gas, ionic conductor, and catalyst). ${ }^{1)}$ Therefore, extension of the TPB length is the most important step for improving SOFC performance. Kinetically, a large TPB area can provide high performance. However, $\mathrm{Ni}$ in the Ni-YSZ cermet anode easily aggregates during long-term operation at high temperature. Such coarse Ni particles may reduce the TPB area. Moreover, the reduction of porosity due to the coarsening phenomenon suppresses gas diffusion. In this regard,

${ }^{\dagger}$ Corresponding author : Ki-Tae Lee

E-mail : ktlee71@jbnu.ac.kr

Tel : +82-63-270-2290 Fax : +82-63-270-2386 restraining $\mathrm{Ni}$ aggregation has been the focus of a great deal of research(e.g., infiltration of catalysts into a porous anode support, mechano-chemical mixing, and core-shell structure) ${ }^{2,3)}$ Meanwhile, the TPB length in the Ni-YSZ cermet anode is strongly influenced by initial morphological factors such as the grain size, connectivity between grains, and porosity. Therefore, the morphology of the starting powder is an important factor in control of the final microstructure of the cermet anode, which affects the overall electrochemical performance.

Spray pyrolysis is a popular synthesis method for producing spherical and uniform ceramic powders. ${ }^{4)}$ Ultrasonic spray pyrolysis (USP), in particular, allows modification of the powder morphology easily by controlling several parameters, including solution preparation, atomizing frequency, flow rate, and heating temperature.$^{5-7)}$ Compared with powder particles prepared conventionally by solid state reaction, the powders synthesized using USP have a narrower particle-size distribution, a controllable particle-size range of 0.1-100 $\mathrm{mm}$, and high purity. Moreover, good dispersion of the spherical particles, with a narrow particle-size distribution is very easy to achieve in any solvent, for preparation of stable paste or slurry, and may suppress abnormal grain growth during the high temperature sintering step. ${ }^{8)}$

In this study, spherical NiO-YSZ composite powder particles were synthesized using ultrasonic spray pyrolysis (USP) with various precursor $\mathrm{pH}$ and carrier-gas flow-rates. Morphology, phase, and performance of the anodes were investigated. 


\section{Experimental Procedure}

Spherical NiO-YSZ composite powder particles were synthesized by ultrasonic pyrolysis using the multi-zone furnace illustrated in Fig. 1. $\mathrm{Ni}\left(\mathrm{CH}_{3} \mathrm{COO}\right)_{2} \cdot 4 \mathrm{H}_{2} \mathrm{O}$ (Alfa Aesar, $98 \%$ ), $\mathrm{Y}\left(\mathrm{NO}_{3}\right)_{3} \cdot 6 \mathrm{H}_{2} \mathrm{O}$ (Daejung Chemical), and $\mathrm{ZrO}\left(\mathrm{NO}_{3}\right)_{2}$. $6 \mathrm{H}_{2} \mathrm{O}$ (Kanto Chemical) were used as starting materials. All compositions of the NiO-YSZ powders were designed with $60 \mathrm{vol} \%$ of $\mathrm{Ni}$ and $40 \mathrm{vol} \%$ of YSZ after final reduction of $\mathrm{NiO}$ to $\mathrm{Ni}$. A calculated amount of $\mathrm{Ni}\left(\mathrm{CH}_{3} \mathrm{COO}\right)_{2} \cdot 4 \mathrm{H}_{2} \mathrm{O}$ was dissolved in de-ionized water to make up the $0.25 \mathrm{M}$ precursor solution. In another beaker, $\mathrm{Y}\left(\mathrm{NO}_{3}\right)_{3} \cdot 6 \mathrm{H}_{2} \mathrm{O}$ and $\mathrm{ZrO}$ $\left(\mathrm{NO}_{3}\right)_{2} \cdot 6 \mathrm{H}_{2} \mathrm{O}$ for $\mathrm{YSZ}$, were also dissolved in de-ionized water. Nitric acid was added into the nitrate solutions to adjust the $\mathrm{pH}$. The prepared $\mathrm{Ni}$ and YSZ precursor solutions were mixed by stirrer. The mixed solution was atomized to a mist by an ultrasonic atomizer. The generated mists were then carried into the multi-zone furnace with $200^{\circ} \mathrm{C}, 400^{\circ} \mathrm{C}, 800^{\circ} \mathrm{C}$, and $1000^{\circ} \mathrm{C}$ heating zones by a carriergas of air at flow rates of $1 \mathrm{~L} / \mathrm{min}, 3 \mathrm{~L} / \mathrm{min}$, and $5 \mathrm{~L} / \mathrm{min}$. During passage through the furnace, the mists decomposed and the decomposed powders collected on filter paper. The collected powder particles do not need any further heat treatment.

The decomposition and reaction temperatures of the precursors were determined by thermogravimetric analysis (TGA, Q600, TA instrument Ltd., USA). Phase analysis for the as-synthesized powders was carried out by X-ray diffraction (XRD). The morphology was investigated by scanning electron microscopy (SEM) and field emission scanning electron microscopy (FE-SEM) with energy-dispersive X-ray spectroscopy (EDX).

Electrolyte-supported-type single cells were used for the evaluation of electrochemical performance. $\mathrm{Ce}_{0.9} \mathrm{Gd}_{0.1} \mathrm{O}_{1.95}$ (GDC) electrolyte pellets $0.5 \mathrm{~mm}$ thick were sintered at $1500^{\circ} \mathrm{C}$ for $4 \mathrm{~h}$ in air. The anode and reference electrodes were deposited by the screen-printing method. The anode paste used for screen-printing was made by mechanical mixing of the prepared powder and an ink vehicle (Heraeus V006). The weight ratio of powder to ink vehicle was 60 : $40 \mathrm{wt} \%$. A reference electrode with the same composition as the anode was also printed next to the anode. The anode and reference electrodes printed on the GDC electrolyte pellet were sintered at $1250^{\circ} \mathrm{C}$ for $2 \mathrm{~h}$. The geometrical area of

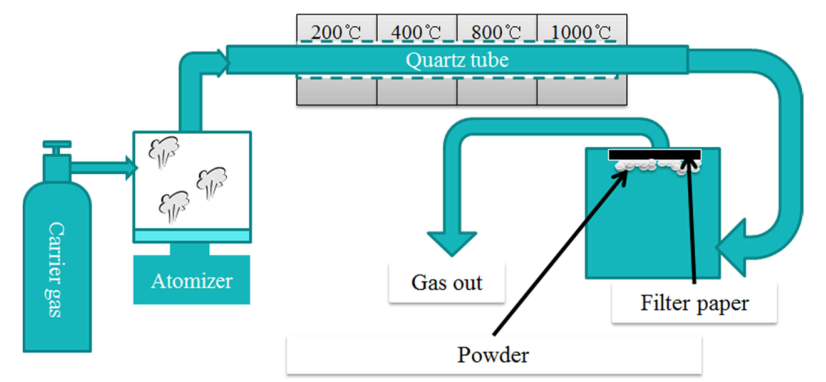

Fig. 1. Illustration of ultrasonic spray pyrolysis (USP) with multi-zone furnace. the anode and the reference electrode was $0.25 \mathrm{~cm}^{2}$ and $0.125 \mathrm{~cm}^{2}$, respectively. The cathode was the composite material of $\mathrm{Ba}_{0.5} \mathrm{Sr}_{0.5} \mathrm{Co}_{0.8} \mathrm{Fe}_{0.2} \mathrm{O}_{3-8}-\mathrm{Ce}_{0.9} \mathrm{Gd}_{0.1} \mathrm{O}_{1.95}$ (BSCF-GDC). The BSCF-GDC powder was synthesized by a modified solgel combustion method. ${ }^{9)}$ The cathode paste was prepared in the same manner as for the anode, and then printed on the GDC pellet, on the opposite side from the anode. The printed cathode was sintered at $1050^{\circ} \mathrm{C}$ for $2 \mathrm{~h}$.

The electrochemical performance of the anode materials was evaluated by AC impedance analysis and a currentvoltage (I-V) test, with a single cell. A PYREX ${ }^{\circledR}$ ring and paste were used for sealing between the alumina tube and the GDC electrolyte at the anode side. Humidified hydrogen ( $3 \% \mathrm{H}_{2} \mathrm{O}$ at room temperature) and dry air were supplied to the anode and cathode sides, respectively, with a flow rate of $100 \mathrm{~mL} / \mathrm{min}$. $\mathrm{NiO}$ in the $\mathrm{NiO}-\mathrm{YSZ}$ anode was reduced to $\mathrm{Ni}$ in-situ during the single-cell test. AC-impedance spectroscopy was carried out with a potentiostat (SP150, Biologic SAS, France) which analyzes frequency response at $800^{\circ} \mathrm{C}$ in humidified $\mathrm{H}_{2}$. The applied frequency was in the range of $1 \mathrm{mHz}$ to $1 \mathrm{MHz}$ with a voltage amplitude of $10 \mathrm{mV}$.

\section{Results and Discussion}

A TGA plot of the mixed-precursor solution of Ni acetate, $\mathrm{Y}$ nitrate, and $\mathrm{Zr}$ nitrate-oxide-dehydrate, is shown in Fig. 2. The weight loss around $220^{\circ} \mathrm{C}$ corresponds to the decomposition of $\mathrm{Ni}$ acetate, and the weight loss around $394^{\circ} \mathrm{C}$ corresponds to the decomposition of $\mathrm{Y}$ and $\mathrm{Zr}$ nitrates. Based on these results, the first, second, and third heating zones were set at $200^{\circ} \mathrm{C}, 400^{\circ} \mathrm{C}$, and $800^{\circ} \mathrm{C}$, respectively. Since particle ordering is critical to forming spheres, the heating zone at $800^{\circ} \mathrm{C}$ was extended to provide enough time for the particles to stay in the heating zone for a sufficient interval. The temperature of the last zone was held at $1000^{\circ} \mathrm{C}$ in order to get crystalline YSZ. It is well known that YSZ exists in an amorphous phase below $1000^{\circ} \mathrm{C}$. Meanwhile, two different $\mathrm{pH}$ values (2 and 4) were used for the precursor solution, because precipitation occurred when $\mathrm{pH}$ was over 4 .

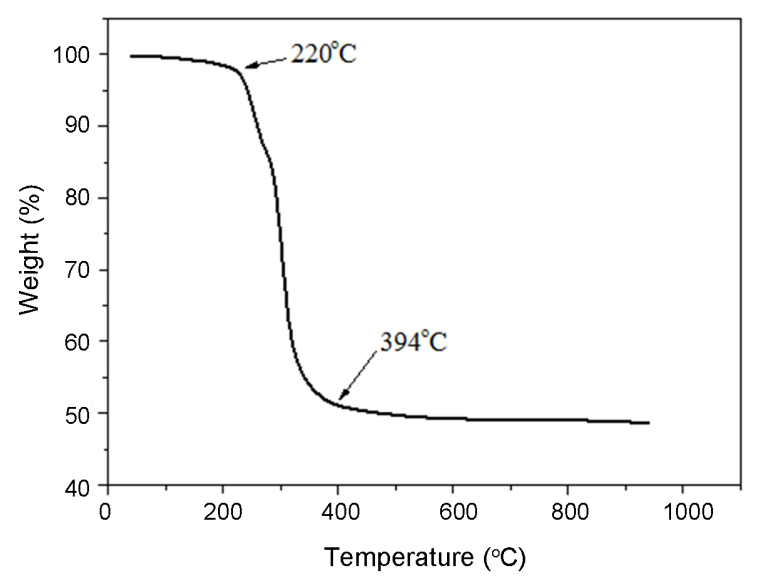

Fig. 2. TGA data of the precursor solution of Ni acetate, $\mathrm{Y}$ nitrate, and $\mathrm{Zr}$ nitrate oxide dehydrate mixture. 
XRD patterns of the as-synthesized NiO-YSZ powders are shown in Fig. 3. All of the powders showed a single phase without any impurities, even without any post-heat treatment. All peaks of the as-synthesized powders well matched those of NiO (JCPDS card no. 47-1049) and YSZ (JCPDS card no. 38-1437), respectively. The crystallite sizes calculated by Scherrer's equation are listed in Table 1. It was confirmed that the as-synthesized powders consisted of very small crystallites of $\mathrm{NiO}$ and $\mathrm{YSZ}(\sim 10 \mathrm{~nm})$. Interestingly, there was no significant difference in the size of the $\mathrm{NiO}$ and YSZ crystallites.

Figure 4 shows SEM micrographs of the as-synthesized $\mathrm{NiO}-Y S Z$ particles. All the particles have spherical shapes of less than $1 \mathrm{\mu m}$ diameter. The particle size of the as-synthesized powder decreased, with increasing $\mathrm{pH}$ of the precursor solution. Interestingly, the powders synthesized at $\mathrm{pH} 4$ have a rather rough surface morphology while those synthesized at $\mathrm{pH} 2$ were hollow spheres with a smooth surface. Kawano et al. reported that differences in the $\mathrm{pH}$ of the precursor solution affects the chemical environment in the vicinity of the cations, consequently leading to differences in the surface morphology of the as-synthesized powder. ${ }^{7)}$ In the high $\mathrm{pH}$ range, acetate counter ions were located close to cations (e.g., $\mathrm{Ni}^{2+}, \mathrm{Zr}^{4+}$, and $\mathrm{Y}^{3+}$ ) and reacted with air exothermically during the drying and aggregation process. This

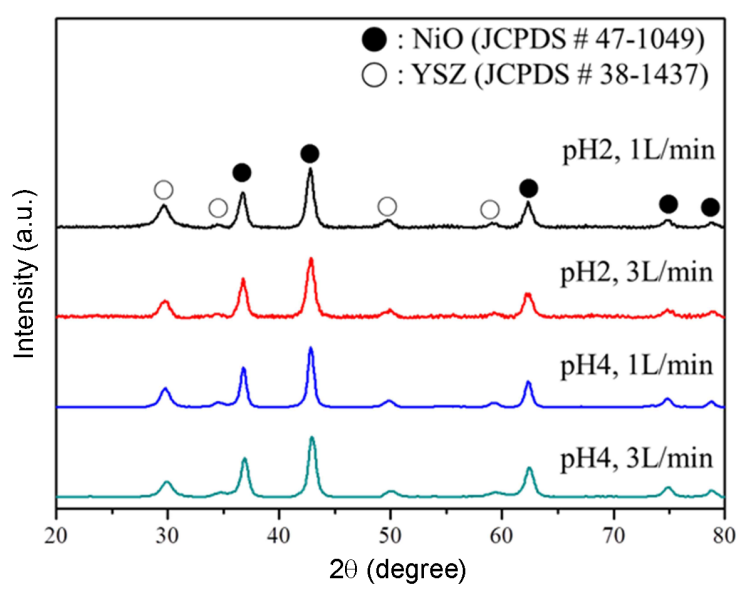

Fig. 3. XRD patterns of the NiO-YSZ particles synthesized by USP with multi-zone furnace.

Table 1. Calculated Size of NiO-YSZ Crystallites Synthesized by USP with Multi-zone Furnace

\begin{tabular}{ccc}
\hline $\begin{array}{c}\text { Precursor } \mathrm{pH} \text { and flow rate } \\
\text { of carrier gas }\end{array}$ & Component & $\begin{array}{c}\text { Crystallite size } \\
(\mathrm{nm})\end{array}$ \\
\hline \multirow{2}{*}{$\mathrm{pH} 2,1 \mathrm{~L} / \mathrm{min}$} & $\mathrm{NiO}$ & 12.9 \\
& $\mathrm{YSZ}$ & 10.8 \\
$\mathrm{pH} 2,3 \mathrm{~L} / \mathrm{min}$ & $\mathrm{NiO}$ & 12.6 \\
& $\mathrm{YSZ}$ & 10.6 \\
$\mathrm{pH} 4,1 \mathrm{~L} / \mathrm{min}$ & $\mathrm{NiO}$ & 14.3 \\
& $\mathrm{YSZ}$ & 10.2 \\
$\mathrm{pH} 4,3 \mathrm{~L} / \mathrm{min}$ & $\mathrm{NiO}$ & 12.2 \\
& $\mathrm{YSZ}$ & 9.2 \\
\hline
\end{tabular}

rapid exothermic reaction leads to a rough surface. On the other hand, in the low $\mathrm{pH}$ range, large numbers of nitrate ions associate with cations and decompose endothermically at a slow rate, which leads to a smooth surface.

Meanwhile, a non-uniform particle size distribution was observed at high flow-rates of the carrier gas. This was due to insufficient time for the particles to rearrange in the droplet, given the high flow-rate of the carrier gas. During the decomposition reaction of the precursor, gases such as $\mathrm{H}_{2} \mathrm{O}, \mathrm{N}_{2}, \mathrm{NO}$, and $\mathrm{CO}_{2}$ are produced, and push the metaloxide particles to the outer surface of the particles. Therefore, there must be sufficient time in the reaction zone for the droplets to form fine particles with uniform size and smooth surface morphology.

FE-SEM images and EDS line-scanning spectra for the synthesized powders are shown in Fig. 5. The $\mathrm{Zr}$ and $\mathrm{Ni}$ spectra overlapped over the whole particle. Moreover, the intensity of the $\mathrm{Zr}$ and Ni spectra were similar. This indicates that $\mathrm{NiO}$ and YSZ particles were well mixed in the composite.

Figure 6 shows typical AC-impedance spectra and current-voltage (I-V) test results of the Ni-YSZ anode materials synthesized by USP at various $\mathrm{pH}$ values of the precursor solution, at a flow rate of $1 \mathrm{~L} / \mathrm{min}$, compared with the conventionally mixed $\mathrm{Ni}-\mathrm{YSZ}$ anode, measured at $800^{\circ} \mathrm{C}$. An equivalent circuit consisting of an inductor (L), a resistor $\left(R_{0}\right)$, and two $R Q$ elements $\left(R_{1} Q_{1}\right.$ and $\left.R_{2} Q_{2}\right)$ was used to fit the AC impedance data. Meanwhile, the total polarization resistance $\left(R_{p}\right)$ can be separated into $R_{1}$ and $R_{2}$, which corresponds to the high-frequency and low-frequency arcs, respectively. The individual electrode reaction processes can be verified by comparing $R_{1}$ and $R_{2}$ values. Separated polarization-resistance values for the Ni-YSZ anodes from Fig. 6(a), are listed in Table 2. The Ni-YSZ anode prepared by USP shows a much lower $R_{p}$ value than the conventionally mixed Ni-YSZ anode. The overall $R_{p}$ value for the $\mathrm{Ni}$ YSZ anode prepared by USP decreased with increasing $\mathrm{pH}$

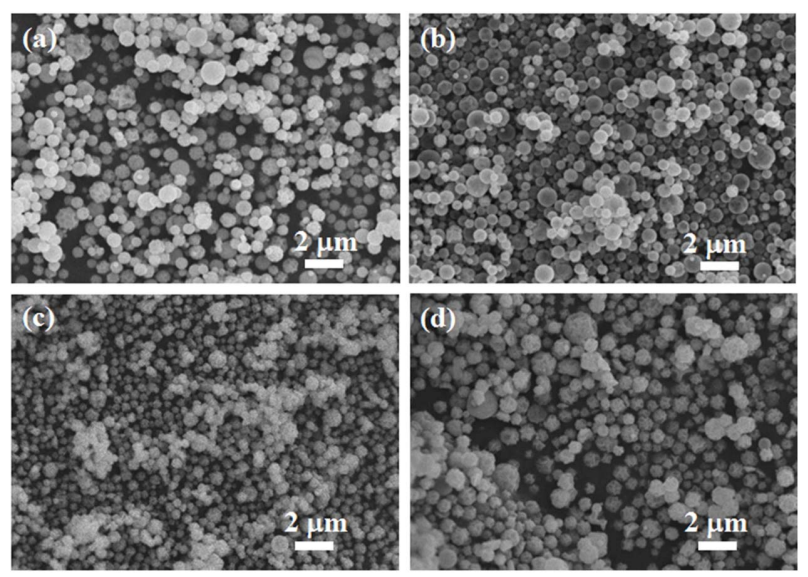

Fig. 4. SEM micrographs of the NiO-YSZ particles synthesized by USP with multi-zone furnace: (a) $\mathrm{pH} 2,1 \mathrm{~L} /$ min, (b) $\mathrm{pH} 2,3 \mathrm{~L} / \mathrm{min}$, (c) $\mathrm{pH} 4,1 \mathrm{~L} / \mathrm{min}$, and (d) $\mathrm{pH} 4$, $3 \mathrm{~L} / \mathrm{min}$. 

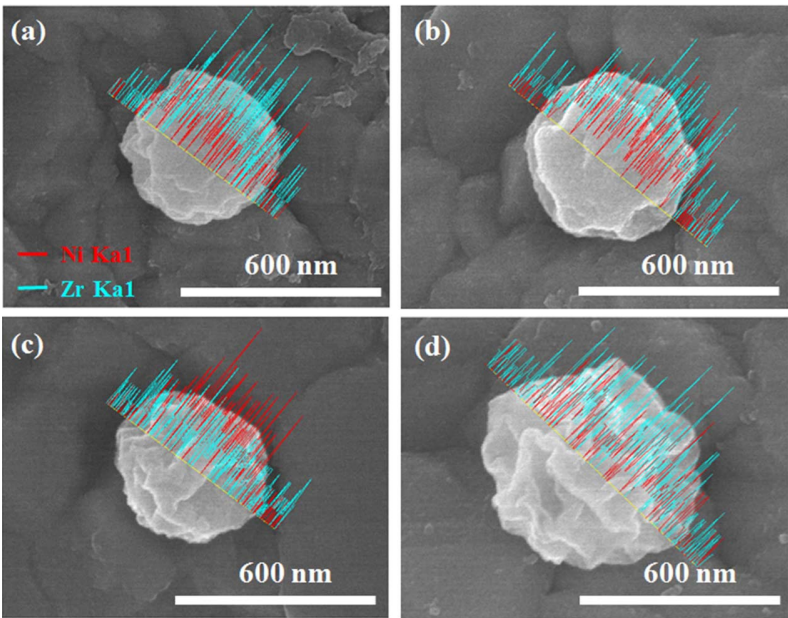

Fig. 5. FE-SEM micrographs and EDX line scanning spectra of the NiO-YSZ particles synthesized by USP with multi-zone furnace: (a) $\mathrm{pH} 2,1 \mathrm{~L} / \mathrm{min}$, (b) $\mathrm{pH} 2,3 \mathrm{~L} / \mathrm{min}$, (c) $\mathrm{pH} 4,1 \mathrm{~L} / \mathrm{min}$, and (d) $\mathrm{pH} 4,3 \mathrm{~L} / \mathrm{min}$.

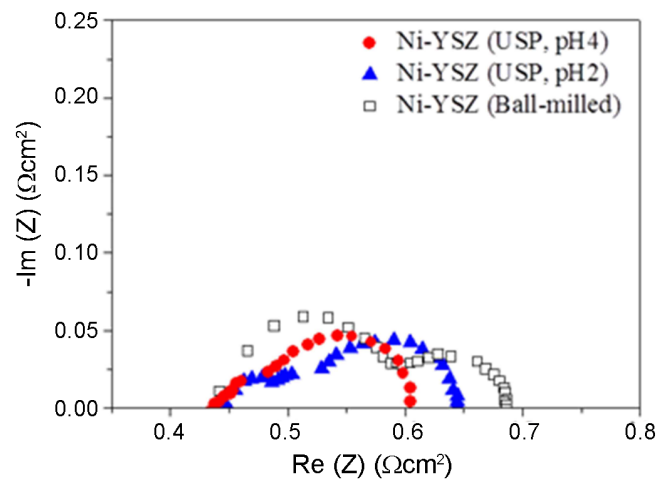

(a)

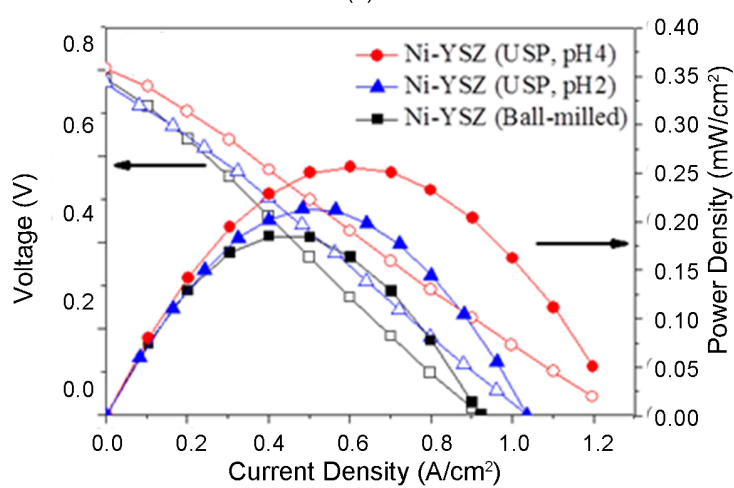

(b)

Fig. 6. (a) AC impedance spectra and (b) single-cell performance data of a Ni-YSZ anode synthesized by USP with precursor solutions of various $\mathrm{pH}$, at a flow rate of $1 \mathrm{~L} / \mathrm{min}$, compared with a conventionally-mixed NiYSZ anode, measured at $800^{\circ} \mathrm{C}$ with humidified $\mathrm{H}_{2}$ fuel.

of the precursor solution. It is well known that the high-frequency $\left(R_{1}\right)$ and the low-frequency $\left(R_{2}\right)$ arcs correspond to the activation and diffusion processes, respectively. ${ }^{10)}$ Interestingly, while the Ni-YSZ anode prepared by USP exhib-
Table 2. Electrochemical Performance a Ni-YSZ Anode Prepared by USP with Various $\mathrm{pH}$ of the Precursor Solution at a Flow Rate of $1 \mathrm{~L} / \mathrm{min}$ Measured at $800^{\circ} \mathrm{C}$ with Humidified $\mathrm{H}_{2}$ Fuel

\begin{tabular}{ccccc}
\hline Anode & \multicolumn{2}{c}{ Area specific resistance $\left(\Omega \cdot \mathrm{cm}^{2}\right)$} & \begin{tabular}{c} 
Maximum \\
power density \\
\cline { 2 - 4 }$\left(\mathrm{mW} / \mathrm{cm}^{2}\right)$
\end{tabular} \\
\cline { 2 - 4 } $\mathrm{R}_{1}$ & $\mathrm{R}_{2}$ & $\mathrm{R}_{\mathrm{p}}$ & 213 \\
$\begin{array}{c}\text { Ni-YSZ } \\
\text { (USP, pH2) } \\
\begin{array}{c}\text { Ni-YSZ } \\
\text { (USP, pH4) }\end{array}\end{array}$ & 0.067 & 0.133 & 0.200 & 256 \\
$\begin{array}{c}\text { Ni-YSZ } \\
\text { (Ball-milled) }\end{array}$ & 0.163 & 0.085 & 0.248 & 185 \\
\hline
\end{tabular}

ited greater values for $R_{2}$ than for $R_{1}$, the conventionally mixed Ni-YSZ anode exhibited an $R_{1}$ value considerably larger than for $R_{2}$. This indicates that the charge-transfer reaction at the Ni-YSZ anode prepared by USP occurs much faster than that at the conventionally mixed Ni-YSZ anode. This might be due to well-dispersed nano-sized Ni and YSZ particles in the Ni-YSZ anode prepared by USP, with a consequent increase in the TPB area.

Cell voltages and power densities, with current density, are shown in Fig. 6(b). The open-circuit voltage of the single cells with Ni-YSZ-pH2, Ni-YSZ-pH4, and conventionally mixed Ni-YSZ anodes was $0.77,0.81$, and $0.78 \mathrm{~V}$, respectively. The relatively lower open-circuit voltage, compared to that of the single cell with YSZ electrolyte, is due to the reduction of the GDC electrolyte in a reducing atmosphere. The maximum power densities of the single cells with NiYSZ-pH2, Ni-YSZ-pH4, and conventionally mixed Ni-YSZ anodes, were 213,256 , and $185 \mathrm{~mW} / \mathrm{cm}^{2}$, respectively, at $800^{\circ} \mathrm{C}$. This single-cell performance result is consistent with the trend observed in the AC-impedance data.

Figure 7 shows the area-specific resistance (ASR) values for the Ni-YSZ anodes synthesized by USP, with precursor solution at $\mathrm{pH} 4$, and a flow rate of $1 \mathrm{~L} / \mathrm{min}$; synthesized by the conventional ball-milling method, measured in humidified $\mathrm{H}_{2}$ at $800^{\circ} \mathrm{C}$ for $500 \mathrm{~h}$. ASR values at the initial stage increase significantly due to the reconstruction of a porouselectrode microstructure. In the case of the conventionallymixed Ni-YSZ anode, the ASR value kept increasing with operation time, which indicates performance degradation. On the other hand, the Ni-YSZ anode synthesized by USP did not exhibit any performance degradation, even after 500 h. It is well known that degradation at the anode during long-term operation is mainly due to microstructural change caused by $\mathrm{Ni}$ coarsening and aggregation, consequently leading to a decrease in the TPB area.

In order to confirm the microstructural degradation, SEM observation was carried out before and after the long-term stability test. As shown in Fig. 8, there was no significant change in the microstructure of the Ni-YSZ anode synthesized by USP before or after the long-term stability test, compared to the microstructure of the conventionally-mixed Ni-YSZ anode. The well distributed nano-sized YSZ parti- 


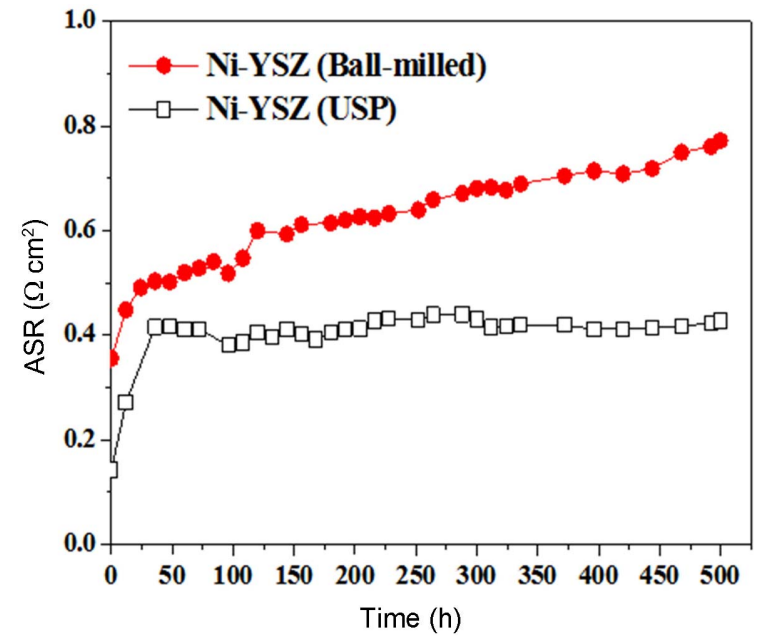

Fig. 7. Comparison of area-specific resistance (ASR) for the Ni-YSZ anodes synthesized by USP with precursor solution of $\mathrm{pH} 4$, at a flow rate of $1 \mathrm{~L} / \mathrm{min}$, synthesized by conventional ball-milling, and measured at $800^{\circ} \mathrm{C}$ with humidified $\mathrm{H}_{2}$ fuel.

cles in the Ni-YSZ anode synthesized by USP may suppress $\mathrm{Ni}$ coarsening. On the other hand, coarse Ni particles were easily observed after long-term operation of the conventionally-mixed Ni-YSZ anodes.

\section{Conclusions}

The main advantage of using ultrasonic spray pyrolysis (USP) with a multi-zone furnace is to obtain NiO-YSZ powders continuously, without post-heat treatment. During the USP process, both $\mathrm{NiO}$ and YSZ primary particles, in the form of nano-size powder, are well-mixed and spherical. The Ni-YSZ cermet anode prepared by USP exhibited better electrochemical performance than the conventional Ni-YSZ mixed by ball-milling. This is due to a significant increase in the three-phase boundary (TPB) area caused by thorough dispersion of the nano-sized Ni and YSZ particles. Moreover, the well dispersed YSZ particles in the Ni-YSZ cermet anode prepared by USP can restrain Ni coarsening and the resulting microstructural change, which consequently leads to the stable electrochemical performance during even longterm operation, without significant degradation.

\section{Acknowledgment}

This research was supported by a grant from the Fundamental R\&D Program for Core Technology of Materials funded by the Ministry of Knowledge Economy, Republic of Korea.

\section{REFERENCES}

1. R. N. Singh, "Sealing Technology for Solid Oxide Fuel Cells
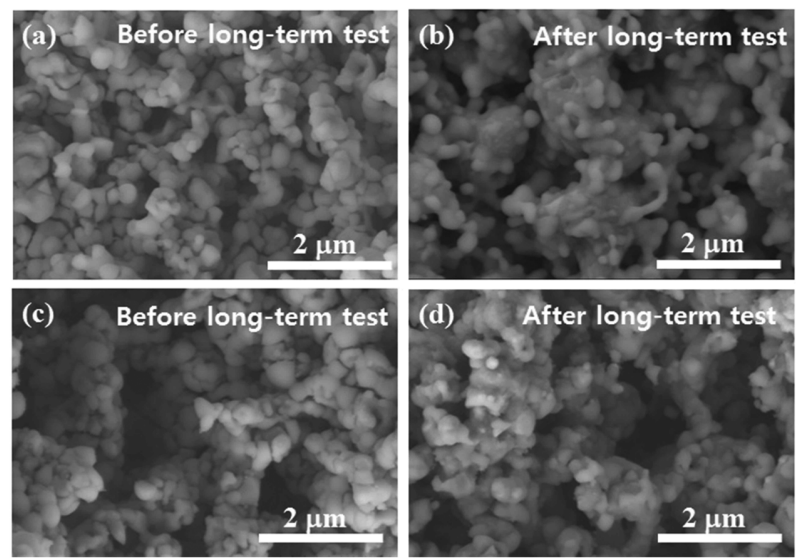

Fig. 8. Back-scattered SEM micrographs of the Ni-YSZ anodes synthesized by $(\mathrm{a}, \mathrm{b})$ USP with precursor solution at $\mathrm{pH} 4$ at a flow rate of $\mathrm{l} \mathrm{L} / \mathrm{min}$ and (c, d) synthesized by conventional ball-milling, before and after a longterm test.

(SOFC)," J. Appl. Ceram. Tech., 4 [2] 134-44 (2007).

2. S. P. Jiang, "A Review of Wet Impregnation: An Alternative Method for the Fabrication of High Performance and NanoStructured Electrodes of Solid Oxide Fuel Cells," Mater. Sci. Eng. A, 418 [1-2] 199-210 (2006).

3. T. Jukui, K. Murata, S. Ohare, H. Abe, M. Naito, and K. Nogi, "Morphology Control of Ni-YSZ Cermet Anode for Lower Temperature Operation of SOFCs," J. Power Sources, 125 [1] 17-21 (2004).

4. K. L. Seo and C. S. Ri, "Synthesis and Characterization of Titania Partially Stabilized Zirconia by Ultrasonic Spray Pyrolysis," J. Kor. Chem. Soc., 44 592-99 (2000).

5. T. Fukui, S. Ohara, M. Naito, and K. Nogi, "Performance and Stability of SOFC Anode Fabricated from NiO-YSZ Composite Particles," J. Power Sources, 110 [1] 91-95 (2002).

6. S. Suda, S. Takahashi, M. Kawano, H. Yoshida, and T. Inagaki, "Effects of Atomization Conditions on Morphology and SOFC Anode Performance of Spray Pyrolyzed NiO$\mathrm{Sm}_{0.2} \mathrm{Ce}_{0.8} \mathrm{O}_{1.9}$ Composite Particles," Solid State Ionics, 177 [13-14] 1219-25 (2006).

7. M. Kawano, H. Yoshida, K. Hashino, H. Ijichi, S. Suda, K. Kawahara, and T. Inagaki, "Studies on Synthetic Conditions of Spray Pyrolysis by Acids Addition for Development of Highly Active Ni-SDC Cermet Anode," Solid State Ionics, 177 [37-38] 3315-21 (2006).

8. M. Gaudon, E. Djurado, and N. H. Menzler, "Morphology and Sintering Behaviour of Yttria Stabilised Zirconia (8YSZ) Powders Synthesized by Spray Pyrolysis," Ceram. Int., 30 [8] 2295-303 (2004).

9. S. P. Jiang and S. H. Chan, "A Review of Anode Materials Development in Solid Oxide Fuel Cells," J. Mater.Sci., 39 [14] 4405-39 (2004).

10. N. Nakagawa, H. Sakurai, K. Kondo, T. Morimoto, K. Hatanaka, and K. Kato, "Evaluation of the Effective Reaction Zone at $\mathrm{Ni} /(\mathrm{NiO}) /$ Zirconia Anode by Using an Electrode with a Novel Structure," J. Electrochem. Soc., 142 [10] 3474-79 (1995). 